\title{
Capabilities of Entrepreneurial Ventures that Successfully Navigate Regime Change: A Research Agenda
}

\section{Julia Ivy}

Executive Professor, D'Amore-McKim School of Business, Northeastern University, Boston, USA

*Correspondence: Julia Ivy, j.ivy@northeastern.edu

\begin{abstract}
The study provides a framework and research agenda for investigating factors that contribute to the sustainability and growth of entrepreneurial ventures operating in environments of regime change. The suggested framework builds on Herbert Simon's [1] science of design, as later extended to concepts of entrepreneurship as creation [2] and effectuation [3], in order to describe the nature of entrepreneurial actions in an environment of regime change. The framework integrates theory on organizational capabilities [4] to locate mechanisms behind entrepreneurs' successful efforts to equip their ventures with capabilities for sustainability and growth. The study offers a pragmatism-driven methodology for studying ventures as artifacts created by entrepreneurs that practice the even-if principle of non-predictable control when navigating the challenges of regime change.
\end{abstract}

Keywords: Regime change, Science of design, Entrepreneurship creation, Effectuation, Dynamic capabilities, Ordinary capabilities, Pragmatism.

\section{ARTICLE INFORMATION}

Author(s): Julia Ivy

Received: 28 Aug 2020; Accepted: 09 Sep, 2020; Published: 25 Sep, 2020 ;

e-ISSN: 2347-4696;

Paper Id: BMN-IJBMR-2020-5;

Citation:

Webpage-link:

\begin{tabular}{|l|}
\hline CrOSSTef member \\
\hline CROSSREF.ORG \\
THECITATION LNKING BACKBONE \\
\hline
\end{tabular}

https://ijbmr.forexjournal.co.in/archive/volume-8/ijbmr-080303.html

\section{INTRODUCTION}

Entrepreneurs who operated in Belarus in the early 1990s found themselves navigating their businesses through two extreme incidents of regime change: first, the collapse of the Soviet Union and the establishment of a market economy and, later, the rollback of the market economy to a state-controlled economy under the political dictatorship of President Lukashenko [5-7]. Of the many entrepreneurial ventures that were launched during these years, many had ceased their operations by 2000 , while others managed to sustain themselves and grow amid the shifting conditions $[6,8]$. This study seeks to help solve the puzzle of why certain entrepreneurial ventures have been able to succeed and thrive under conditions of government regime change while others have not by presenting a research agenda for identifying the factors differentiating these two groups.

The work that follows has become highly relevant and significant in these times, when, after 26 years of Lukashenko's regime, Belarusians are rising up to fight for their freedom $[9,10]$. Whether the current uprising succeeds or is suppressed, a new population of entrepreneurs will be faced with the challenge of adapting either to open markets and high uncertainty or to an authoritarian economic backlash. Beyond Belarus, the research framework presented here is meant to be applied to entrepreneurial ventures working in any regime change context across the globe [11,12].

In endeavoring to investigate sources of sustainability and growth in entrepreneurial ventures operating in an environment of regime change, the study refers to concepts related to the science of design $[1,13,14]$ later developed to apply to concepts of creation [2] and effectuation [3], as well as to the area of organizational capabilities $[4,15,16]$. These concepts are united with an ontology of pragmatism with the aim of developing general design propositions to be used in crafting solutions for field problems. The focus here is not only on understanding how a natural (social) system works, but also on developing design propositions as "a chunk of general knowledge, linking an intervention or artifact with an expected outcome or performance in a certain field of application" [17]. The inquiry is expected to arrive at propositions formulated in the form of "technological rules" $[14,18]$ that follow the formula "if you want to achieve $\mathrm{Y}$ in situation $Z$, then apply intervention $X$," with the emphasis on $\mathrm{X}$ as a solution for a certain type of field problem in a certain context [13]. The goal of this study then is to arrive at a set of propositions and develop a research design for their testing, after which those proven may inform and guide entrepreneurs in building a venture with the capability to navigate and succeed in a context of regime change.

The paper starts with a literature review of design science on 
venture creation and organizational capabilities for entrepreneurship. The discussion of literature on design science and entrepreneurship as artifact creation [2, 3, 19] intends to provide readers with a sense of what entrepreneurship means in the context of regime change. The discussion of the literature on organizational capabilities [4, $15,16,20,21]$ intends to highlight available knowledge informing how entrepreneurs can navigate such a context. The paper then offers an integrative view of the concepts of entrepreneurial action, organizational capability, and artifact design and arrives at a framework for investigating entrepreneurial behaviors for the purpose of identifying a strategic framework for an entrepreneurial venture navigating regime change. Next, the paper suggests a methodology for collecting and categorizing data from a variety of case studies under the framework. The paper concludes with a discussion of the proposed contributions and limitations of the proposed framework.

\section{LITERATURE REVIEW}

\subsection{Entrepreneurship in Times of Uncertainty}

The process of entrepreneurship describes entrepreneurs in action. Action orientation considers entrepreneurship from the point of view of what entrepreneurs actually do and how they act to get the outcomes their actions render [21-23], moving beyond the perception of entrepreneurship as an instrumental "calculator," or a combination of traits, or a combination of networking ties. In this way, action orientation offers a holistic approach, perceiving entrepreneurship to be something an entrepreneur does rather than just who or what an entrepreneur is [21].

Two approaches to entrepreneurial processes predominate in the current literature on entrepreneurship: the opportunitydriven approach [24] and the effectuation approach [3, 25]. Networking arises as a variable in the discovery vs. creation debate [2], both sides of which seek to explain entrepreneurial action in terms of the ability of entrepreneurs to form and exploit opportunities. These approaches refer to two distinct logics underlying entrepreneurial actions: the predictive and goal-driven logic of entrepreneurship and the effectual and means-driven logic of entrepreneurship [26].

Discovery theory assumes that opportunities exist, independent of entrepreneurs, so the goal of entrepreneurs is to explore the opportunities that exist at the market and then act to exploit those they chose [24]. Creation theory assumes that opportunities are not formed by an industry or market; rather, they are created by the actions, reactions, and enactment of entrepreneurs exploring ways to produce new products or services [3, 27]. Creators rely on their means and on developing stakeholder commitment and, by their actions, craft opportunities that might not have existed before the entrepreneurial action, as new artifacts. Engel et al. [19] extend this discussion into networking in the context of uncertainty, claiming that, in a shifting environment, networking becomes an activity out of which the entrepreneur's goals emerge. In, for example, a regime change context wherein an economy is moving from state controlled to emerging markets, the social complexities of networking with actors of the previous regime vs. networking with actors in the emerging markets add a level of precariousness on top of the seismic shifts occurring on the political, legal, and economic landscape.

Proposition 1: In the highly uncertain environment of regime change, an approach of creation and effectuation holds more potential for successful entrepreneurship than the opportunitydriven approach of discovery.

\subsection{Entrepreneurial Ventures as Artifacts}

The view of entrepreneurship as creation and effectuation provides a strong foundation for considering entrepreneurial action for venture development as artifacts. While different authors use different terminological languages to present their views on entrepreneurship, such as creation theory [2], the effectuation concept [3, 26], the organization as design approach [13, 28], science of artifactual concept [1, 29], or coproduction (Downing, 2005), they share the view that entrepreneurs are reflexive agents [19] who "actively shape their approach to tie formation through thoughtful agency" [30].

"The artifacts of interest to entrepreneurship are the entrepreneur and the firm" [26], where "they are as they are only because of the system's being molded, by goals or purposes, to the environment in which it lives" [1]. Entrepreneurs craft their opportunities and their enterprises to find optimal adjustment between the inner environment, represented by a set of given alternatives of action, and the outer environment, represented by a set of parameters, which "may be known with centrality or only in terms of probability distribution" [31].

The idea of applying probability distribution to decipher environments of high uncertainty grows out of Knight [32], which identifies three types of uncertainty: the known distributions and unknown draws, the unknown distributions and unknown draws, and the non-existent distributions where the very instances are unclassifiable (subsequently known as Knightian uncertainty). Even within this continuum of uncertain environments, entrepreneurship can exist in different 
forms, each of which combines routine and adaptable behaviors. Thus, in an environment of known distributors and unknown draws, entrepreneurs at least know what kind of business opportunities they're looking for. At the same time, in an environment of the highest level of uncertainty, entrepreneurs cannot search for an opportunity, as the entrepreneurial opportunities do not exist until created by the entrepreneurs themselves [2, 3, 29].

In their efforts to connect the inner environment and the outer uncertain environment of their business-related actions, entrepreneurs act on venture development, following two principles [26, 31]. The even-if principle of non-predictive control claims that, even if the future is uncertain and unpredictable, entrepreneurs are still capable of designing the artifacts they desire. The principle of near-decomposability describes the structural aspects of artifacts that are necessary to ensure their stability, providing the architecture of rapidly evolving complex systems. These principles set entrepreneurial ventures among the architectures of complex systems that can be found in the world, both inorganic and organic, ranging from elementary particles to social systems $[26,31]$.

The foundation for understanding entrepreneurship as a process of artifact creation (Selden and Fletcher, 2015 rests on two theoretical pillars. First, entrepreneurship as artifact creation involves the interface of the inner and outer environments [2], where "if the inner environment is appropriate to the outer environment, or vice versa, the artifact will serve its intended purpose" [1]. Second, entrepreneurs adjust their inner environment to the outer environment through networking with stakeholders [26, 33], which directly shapes their ventures. Entrepreneurs start with their inner environment (means) and gradually reach an outer environment through everyday interactions in building commitment with stakeholders, expanding a cycle of resources, defining new goals and new means for their actions, and converting the cycle of transformations of artifact into new markets and other effectual artifacts [26].

Proposition 2: In the context of regime change, entrepreneurial ventures serve as artifacts of entrepreneurship if they pursue a purpose of alignment between the inner and outer environments based on the even-if principle of nonpredictable control.

\subsection{Organizational \\ Entrepreneurial Ventures}

Capabilities

of

The assumptions presented above highlight the necessity to evaluate a venture's underlying capability for sustainability and growth. What organizational capabilities do successful entrepreneurs nurture to prepare their ventures to navigate the vicissitudes of regime change?

The literature defines organizational capabilities as high-level organizational routines (or a collection of routines) that confer upon an organization's management a set of decision options for producing organizational outputs of a particular type [15] organizational routines frame venture behavior that is learned, highly patterned, repetitious or quasi-repetitious, and founded in part in tacit knowledge [16]. While the literature describes organizational capabilities at two levels - ordinary capabilities (or operational processes of repetitive and stable practices meant to be prescribed and repeated) and dynamic capabilities (or a firm's capability to integrate, build, and reconfigure ordinary capabilities for adjustment and change) [21, 34] - the uncertain environment demands the latter.

Few studies of organizational capabilities focus specifically on newly formed entrepreneurial ventures versus established firms [35]. Existing findings suggest that younger firms have some "learning advantages" because they have less to unlearn [36]. They are more ready for improvisation and learning through doing and having to "fight fires" [37], preferring contingency and experimentation, trial-and-error learning, and imitation over careful planning and replication of previously established routines. Newly formed entrepreneurial ventures rely on dynamic capabilities for and by enabling new resources creation for and by alteration of an existing resource base, as well as by creating, integrating, recombining, and releasing resources [4]. They tend to establish a set of simple rules instead of setting opportunities-oriented goals and plans or establishing well-defined routines [4].

The findings of Eisenhardt and Martin [4] suggest simple rules as the most appropriate means of defining practices and routines for a venture seeking to build its capabilities for navigating a high velocity environment. As any other entrepreneurial ventures, entrepreneurs from the post-Soviet state-controlled economy started their activities by applying contingency, experimentation, and trial-and-error learning in search of "specific strategic and organizational processes" [4] that could bridge their means to the realities of the business environment and eventually build up their own set of organizational capabilities. As Eisenhardt and Martin note, in this kind of high-velocity environment, firms tend not to develop organizational capability in the form of "complicated, detailed, analytic processes that rely on existing knowledge and linear execution" [4].

Unlike established companies, new ventures have a limited, focused, simple, and rapidly changing configuration of dynamic capabilities, with increasing integration of skills, recent execution failures, opportunities in previously 
unexplored areas, and major changes in response to demands from their stakeholders or events [35]. In order to navigate the highly uncertain context of regime change, they can draw on these experiences in crafting and following simple rules to connect their inner environment with the "before" and "after" of the outer regime change environment.

Proposition 3: In order to equip their ventures with capabilities to navigate the environment of regime change, entrepreneurs refer to ordinary capabilities acquired in routines followed before the regime change, which allows their ventures to continue. By developing a set of simple rules, they equip their ventures with dynamic capabilities to navigate the context that emerges as a result of the regime change.

\section{PROPOSED SCHEMA FOR FUTURE RESEARCH}

Integration of the above-presented propositions will help to lead future studies to a process model of relations between the path of organizational capabilities entrepreneurs follow and characteristics of the ventures as the artifact they design to navigate the context of regime change (Figure 1). The concept of artifact design clarifies the means, the ends, and the sense of entrepreneurial actions as venture creation when connecting the inner and outer environments. The concept of organizational capabilities provides a structure for understanding entrepreneurial actions themselves and clarifies how exactly entrepreneurs connect the inner environment of resources and competencies accumulated in the pre-change regime with the new outer environment as it emerges out of the regime change.

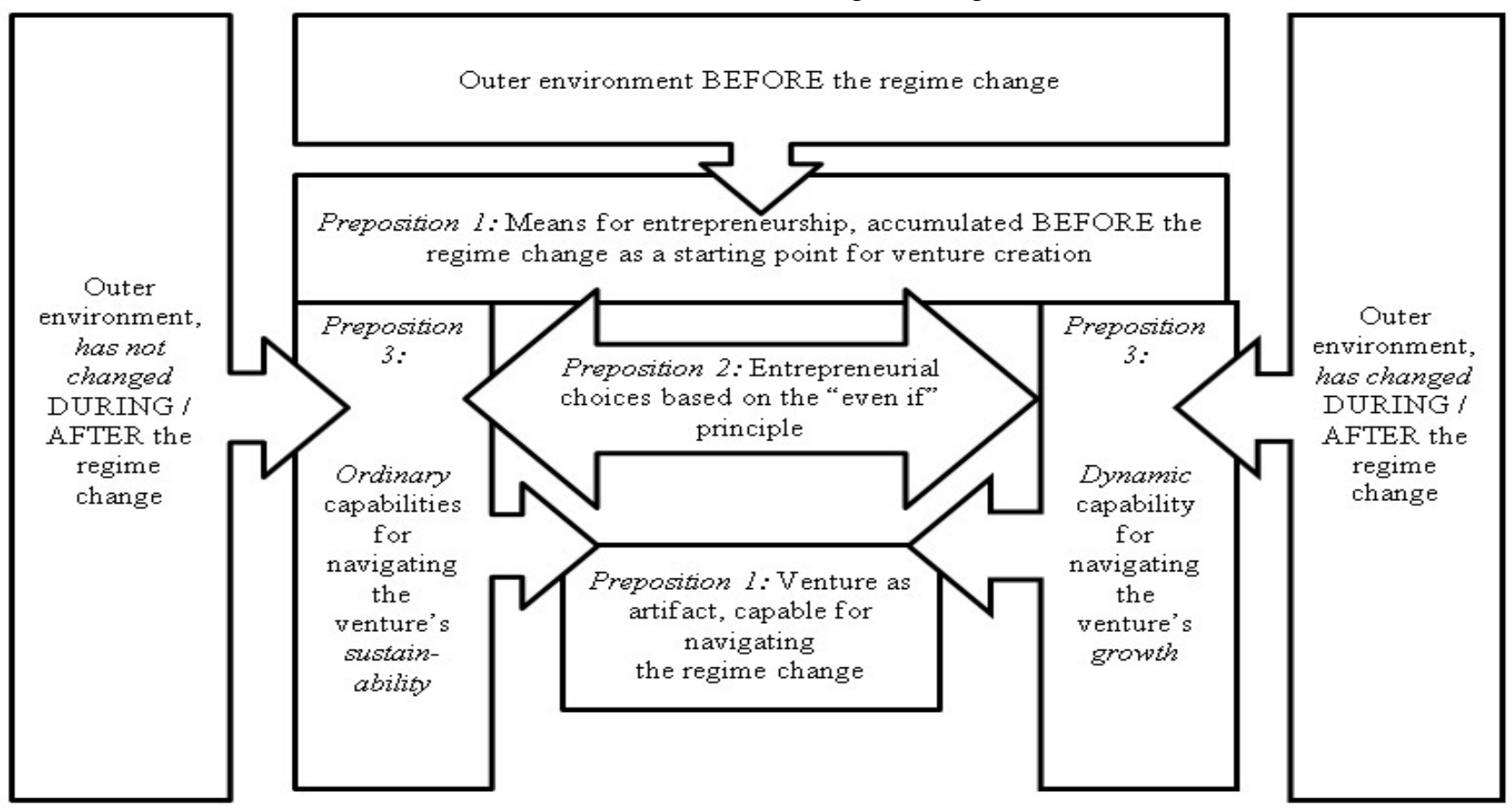

Figure 1: Crafting a Venture, Capable for Sustainably and Growth in the Environment of Regime Change.

In the "working" practices and routines that flow from their firm's particular characteristics, entrepreneurs pass through the following stages of capability development: the founding stage, the development stage, and the maturity stage [38]. In the context of regime change, they first rely on capabilities and resources acquired during the previous regime, or outreach and gain access to stakeholders that were resource brokers in the previous regime, then define simple rules to protect these resources. Concurrently and gradually, they craft their ventures through trial and error in their search for practices and routines that work best for them in the new regime, with its new players, and, again, develop simple rules for navigating the new environment. Relying on means rooted and nurtured in the previous regime, they ensure their ventures' sustainability; openness to practices needed to succeed under the new regime leads to their venture's growth.

\subsection{Importance of Pragmatic Validity}

Design science, accepted as a fundamental approach for understanding entrepreneurial action for venture creation in the context of regime change, provides a direction for designing research. Van Aken and Romme [13] recommend research problems be driven by field problems, as opposed to being driven by pure knowledge problems. The emphasis and 
key to solving field problems should center on solutionoriented knowledge that links systems and behavior to outcomes. The justification for the research should be largely based on pragmatic validity. As a result, such research would aim to generate valid general knowledge to solve field problems $[14,18]$.

As Gerring [39] argues, research "should not be defined by a distinctive method of data collection but rather by the goals of the research relative to the scope of the research terrain" (2007: 68). Given the central role played by shifting economic "terrain," when conducting a study on entrepreneurial actions for venture creation in the context of regime change, it is important to integrate the following into the research design: (a) close participation with professionals in defining the subject of investigation, on the desired product, and even on case selection; (b) close attention to the specifics of the context; and (c) production of knowledge in the form of "rules" that entrepreneurs can apply to their actions in their efforts toward venture creation in the context of regime change.

\subsection{The Role of Casual Process Observation}

While both quantitative and qualitative studies can be applied for testing propositions, qualitative research and "causal process observation" of carefully selected companies promises to collect "data that provides information about context, process or mechanism, and that contributes distinctive leverage in causal inference." Unlike quantitative variableoriented "data set observation," causal process observations show how different aspects mutually contribute to holistic understanding of each particular case. Such a study permits a high level of conceptual validity to identify the indicators of a venture's capabilities for navigating the environment of regime change that best represents the concept under investigation. "This requires a detailed consideration of contextual factors, which is extremely difficult to do in statistical studies but is common in case studies" [40]. Asking one question of individuals, groups, or documents but getting different answers may uncover new hypotheses that can be tested with previously unexamined evidence.

Performing within-case study and cross-case study comparisons, research starts with the "seemingly simple idea that social phenomena in like settings (such as organizations, neighborhoods, cities, countries, regions, cultures, and so on) may parallel each other sufficiently to permit comparing and contrasting them" [41]. This study follows Gerring's [39] guidance that even a single case study can serve well for generating hypotheses, for studying mechanisms of causal insights, and for deep inquiry of the scope of proposition. However, cross-case analyses go farther when looking to generalize from the findings [42], comparing a small number of similar cases matched on all but a few variables and addressing issues of causation by covering both a process and context analysis [43]. Within-case analyses and cross-case analyses both refer to qualitative data, focusing on a whole unit of analysis and providing thick case penetration while emphasizing the role of context. They require careful case selection to overcome limits on generalization and execute causal analysis. Case selection is based on dependent variables of the study - characteristics of entrepreneurial ventures as artifacts.

\subsection{Artifact-Focused Case Selection}

Qualitative researchers constantly face issues concerning relationships between concepts and case selection because they usually have to construct their populations themselves. The same problems are less pressing for large-N quantitative research where most scholars rely on reconstituted populations and take these data sets as a given. If the concept of population is addressed at all in research of this type, it is usually only in relation to the sample: whether the sample drawn by a researcher is adequate for generalizing about the population the researcher wishes to evoke [41].

\begin{tabular}{|c|c|c|}
\hline $\begin{array}{l}\text { Dependent } \\
\text { variables }\end{array}$ & Values & Control Variables \\
\hline Venture Growth & $\begin{array}{l}\text { Opinion of other executives; } \\
\text { Presence at the market and market extension; } \\
\text { Comparison to GDP, competitors' and industries' indicators; } \\
\text { Financial indicators (annual profit and return to investments) }\end{array}$ & $\begin{array}{l}\text { "Nationality" - local } \\
\text { Ownership - private } \\
\text { Size - small and medium enterprises } \\
\text { Start-up financing - self } \\
\text { Relevance to the context of regime } \\
\text { change - operated from _to }\end{array}$ \\
\hline $\begin{array}{l}\text { Venture } \\
\text { Sustainability }\end{array}$ & $\begin{array}{l}\text { Longevity of operation } \\
\text { No significant "downs" } \\
\text { Dynamic of annual sales } \\
\text { Dynamic of organizational development }\end{array}$ & \\
\hline
\end{tabular}

Table 1: Studying Growth and Sustainability of Entrepreneurial Ventures. Dependent Variables and Their Values. 
A study that explores the capabilities of entrepreneurial ventures to sustain and grow in the context of regime change needs to use the criteria of sustainability and growth for case selection. Table 1 above illustrates dependent variables that the author applied in the study of entrepreneurial behavior during the Post-Soviet transition in Belarus.

While specifics relate to the given context, the sustainability of operations is determined by historical evidence on the business under the same name and ownership, and growth is defined by the dynamic of revenue and other matrixes. However, to grow operations in this inhospitable business climate is a more impressive achievement than merely sustaining a business on a small scale. Growth implies thriving, rather than merely getting by. To define "sustainable growth," researchers might defer to interviews with representative professionals involved in other ventures' activity in the same environment directly related to the field problem that the study intends to solve. As an example, in the study of ventures that managed to navigate the post-Soviet regime change in Belarus in 1990, and then another regime change when Belarus shifted back to the Soviet-style regime of Lukashenko in 1995, the researchers asked, "Which private businesses in Belarus can be described as having sustainable growth?" "Why did you choose this company?" [44]. Based on their responses, the study operationalized measures of ventures' growth and sustainability, i.e., presence in the market and market extension; consistent pattern of revenue generation (turnover) reported as "real" (that might differ from the revenue reported to the state officials); ongoing organizational development; growth rate in comparison to competitors and industry group.

The criteria of sustainability and growth may be used to demarcate four categories of the cases under investigation: The HG/HS (high-growth/high-sustainability) group would represent ventures that achieved sustained growth under regime change. The HG/LS (high-growth/low- sustainability) cases would represent ventures that experienced rapid growth during the initial years of their operation but later ceased their operations. The LG/HS cases would represent ventures that did not grow but managed to sustain their previous level of operations through regime change. Finally, the LG/LS group of cases represents ventures that did not manage either sustainability or growth in the context of regime change.

Under the science design approach, researchers work in close collaboration with practitioners in their effort to find solutions for field problems. These are the professionals of the discipline who define dependent variables (outcomes desired) and whose opinion on case selection that can serve as a benchmarking (positive case that does possess desired characteristics) or contrasting (negative case that can possess desired characteristics but does not) option for the field problems.

As an example, in order to place entrepreneurial ventures in each group of cases, researchers may defer to opinions of members of local business networks, which are usually tightknit in emerging economies [7], describing the four categories of cases of interest and asking each informant to name at least two local ventures for each category.

\subsection{Search for Independent Variables as a Solution for Field Problems}

The final stage of research design is to develop a framework for collection of data that will reveal technological rules for how entrepreneurs can create a venture that will be capable of navigating an environment of regime change (Preposition 1). Table 2 illustrates how researchers can record the data on entrepreneurial choices and behaviour regarding to the even-if principle of non-predictable control (Preposition 2), roughly categorizing the observational data into the relevant for the context of regime change. During data collection, using the methodology of casual process observation, researchers observe Xs as independent variables that indicate causes of theoretical interest of the study. Researchers record their observations in the table, with " 1 " indicating revealed relationships between the independent and dependent variables (e.g., "That choice helped my venture to gain fast and sizable growth" or "My relationships with a state representative protected my venture and assured its sustainability"), and " 0 " indicating the absence of correlation between the independent and dependent variables (e.g., "I decided to finish my degree in economics at that time and I hoped to apply that knowledge to my business, but it was a waste of time"). Collection of data from all the cases, and preferably by several researchers, before placing the data into groups of cases based on dependent variables assists researchers in controlling biases regarding the values of independent variables and their categorization.

When the data on all the cases is collected, researchers can categorized those data into groups of cases based on Mill's joint method of agreement and difference (Table 3). Mill's joint method of agreement and difference [40, 45] allows researchers to identify independent variables among the cases associated with common dependent variables, while searching for patterns and commonalities around the cases and asking ourselves "what is really going on here?" $[46,47]$.

With reference to Gerring [39], Table 3 illustrates a simple structure for preparing the data for categorization. "Y" here acts as a dependent variable representing the theoretical interest of the study, which researchers assign during case 
selection, with $\mathrm{Y} 1$ indicating growth and $\mathrm{Y} 2$ indicating sustainability. The coding differentiated among X-descriptors of independent variables reveals analytical categories as a holistic perspective on the issues under investigations -- the approach for creation capabilities of the ventures that successfully navigate regime change.

\begin{tabular}{|l|l|l|l|}
\hline Preposition 1 & \multicolumn{3}{|c|}{ Preposition 2 } \\
\hline Ventures as artifacts & \multicolumn{1}{|c|}{ Entrepreneurial actions: How far these actions rely on the even-if principle of non-predictable } \\
control
\end{tabular}

Table 2: A structure for data collection: Entrepreneurial actions for venture creation.

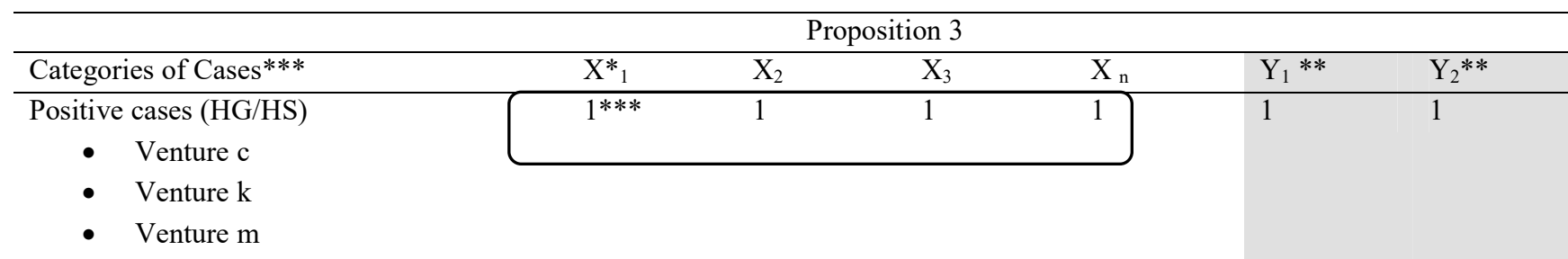

Negative cases (HG/LS)

- Venture a

\begin{tabular}{rlll|}
\hline $0 * * *$ & 0 & 0 & 1 \\
\hline
\end{tabular}

0

1

- Venture d

- Venture b

Negative cases (LG/HS)

- Venture $\mathrm{x}$

\begin{tabular}{|llll|}
\hline 1 & 1 & 0 & 0 \\
\hline
\end{tabular}

1

0

- Venture y

- Venture z

- Venture o

- Venture i

Irrelevant cases (LG/LS)

- Venture 1

\begin{tabular}{|llll}
\hline 0 & 0 & 0 & 0 \\
\hline
\end{tabular}

0

0

- Venture $\mathrm{n}$

*X - a holistic view on independent variables, the data on entrepreneurial behaviour for venture creation (see Table 2)

$* * \mathrm{Y}-$ dependent variables, the data on suitability (Y1) and growth (Y2)

*** Case selection, might be adjusted based on the data on dependent variables (Y), collected during the study

Table 3: A structure for data analysis: Revealing patterns of entrepreneurial behavior for capability creation. 


\section{CONCLUSION}

The goal of this paper is to set an agenda for researching organizational capabilities that provide entrepreneurial ventures with sources of sustainability and growth during the challenging and uncertain times of regime change. Reference to the concepts of creation [2] and effectuation [3, 26], as rooted in the science of design (Simon, 1969), let the study pursue a dual goal of (a) emphasizing the role of entrepreneurs as proactive and reflective agents and (b) setting the stage for a pragmatic approach to research that aims to assist these entrepreneurs develop "technological rules" [18] for venture creation. Reference to the concept of organizational capabilities [4] led the study to explore the nature of such rules.

\subsection{Contributions}

As a conceptual contribution, the paper provides an integrative view on entrepreneurial behavior in a given context, which results in a framework for creation of entrepreneurial ventures as artifacts with particular characteristics of growth and sustainability in a particular context, where the environment of "before" the regime change provides entrepreneurs with means for venture creation, and the environment of "during" the times of regime change provides entrepreneurs with an understanding of the effectiveness of their efforts. This work challenges the discovery vs. creation dichotomy in suggesting a continuum of discovery that moves toward creation through a process of progressing from the "before" to the "within" or "after" the time of regime change, illustrating that the theoretical separation between predictive rationality of discovery and effectuation for creation might empirically be presented in tandem [48], where both predictive and effectual processes may be at work or be present in different combinations-i.e., where some entrepreneurs are more driven to search out opportunity, others are more driven by their means and resources to search out stakeholder commitment, and a third group might combine both approaches.

The study contributes a research methodology for studying the ways in which venture creation can be conducted so as to ensure the venture's pragmatic validity, attention to the voice of involved stakeholders, and grasp of the true realities of the context. As Read et al. indicate, "The end product of effectuation is fundamentally unpredictable at the beginning of the process. Indeed, the opportunity and even the market itself can be an outcome of and generated through the very process of effectuation" (2009: 3-4). The effectual and effective entrepreneur takes action to make the end product emerge. The proposed methodology equips researchers and professionals with a framework for logic of design and highlights its implication for revealing technological rules [18]. Case studies of businesses that have been able to survive and grow in hostile business environments can provide insights and inspiration for business students and practicing managers around the world. The data collected via the methodology presented here can be used to better understand the process of independent business development in countries with transitional and/or unstable economies to help ensure that local practices are studied, appreciated, and constantly compared with internationally accepted models.

In such a way, the study contributes to challenging the Mode 1 approach for its objective of knowledge production for knowledge's sake, where the knowledge must be deemed valid by an informed audience - the relevant scientific community-and be descriptive and theory-driven in its nature. Hambrick [49] voiced it a number of years ago in his speech on "What If the Academy Actually Mattered?" While this rigor vs. relevance discussion has been active for years [50-52], the often missing utility of academic business research products is still seen by many as problematic $[18,53]$. The study contributes in narrowing this gap and setting an agenda of the search of how things work more than in how things really are; it is more interested in "what is useful than in what is true in some cosmic context-free sense" [26].

Finally, while the study has direct practical implications for solving the field problem of how best to establish sustainable and growing ventures in the context of regime change, it also provides benchmarking information for entrepreneurs who intend to develop their ventures in any country with a statecontrolled economy and/or political dictatorship. Managers from Belarus, Turkmenistan, Vietnam, Pakistan, Libya, and Cuba should be interested in these insights. Additionally, multinational corporations will benefit from gaining a deeper understanding of location-decision considerations.

\subsection{Limitations}

The study has some limitations that must be addressed. First, venture creation is not a linear process. It is cyclical. It can start with means and progress to outcomes, or it can start with trial-and-error testing of technological rules and, as it progresses, invoke evaluative means to challenge desired outcomes.

Second, the literature on entrepreneurship is united in accepting the role of networking and stakeholder relationships in venture creation. There is consensus among researchers on the essential role of networking for entrepreneurship [54, 55], with a rich body of publications available on networking values and mechanisms [56, 57]. It is accepted that networking enables entrepreneurs to identify new opportunities, locate and gain access to needed resources, and build legitimacy among external stakeholders [56, 58], Networking both creates and feeds on social capital-defined as accumulated goodwill, engagement, and commitment — which is not only a good thing for entrepreneurship and venture development [57] but a key to venture success [58] and survival [57] or failure [59]. Considering that networking has also become a subject of the discovery vs. creation debate [2], the role of networking with various groups of stakeholders must be taken into account when applying or further developing the framework presented in this study. 


\subsection{Future Scope and Implications of the Study}

Countries that have experienced regime shifts present opportunities for examining the capabilities of entrepreneurial ventures that have managed to survive and even grow in a context of significant economic change $[11,12]$. A systematic and pragmatic analysis of what makes certain entrepreneurship ventures capable of sustainability and growth when transiting a seismic regime shift has yet to be performed. This study contribute to filling this gap by setting an agenda for research in this area and defining the scope for future research.

Transition economies provide a rich environment for furthering our understanding of entrepreneurial behavior at the stage of regime change. There are many transition economies around the world, in different stages of transition. The World Bank study of twenty-two Eastern European and post-Soviet countries [60] shows that these countries follow one of three courses of transformation: radical market-oriented reforms, rent-seeking states, and reinstitution of a state-controlled economy. Each of these different types of economy are often underpinned by particular forms of entrepreneurial behavior during the times of regime change. Furthering our understanding of trust in the transition between different economies is thus a worthwhile area of research. In addition, it would also be fruitful to compare entrepreneurs operate in countries experiencing different kinds of transformations, or at different stages of those transformations. There is, of course, a plethora of opportunities for scholars to explore how entrepreneurship evolves in a multitude of different contexts which can offer new insights into the different environments in which entrepreneurs operate [61] as well as how their actions are embedded within specific local contexts [7, 47].

The study refers to the qualitative methods to explore the unique manifestations of entrepreneurship in an international setting determine what questions should be asked [46]. The next phase in this study could test research findings in another population, perhaps with use of a different methodology. This can include quantitative studies of the extent to which entrepreneurs - in this or other business environments - apply the capabilities we have defined and how far they can be generalized.

Finally, in the search for relevance in the findings of the study, the study is designed around the assumption that to become relevant, the production of knowledge is apt to be casespecific as well as problem-specific [62]. As a direction for future research, the study should avoid the trap of linear knowledge transfer, when "knowledge flows from the domain of science to the one of practice" [63]. The future research should not only continue discussion of the study findings with practicing agents, but also search for the model adjustment and testing on its ability to assist entrepreneurs in venture development. Joint effort and interest of science and practice in knowledge production should lead us to the non-linear knowledge production, where the "knowledge informs action, and that action becomes knowable if we understand better the underlying principles that link cause and effect" [64].

\section{REFERENCES}

[1] Simon, H. A. (1969/1996). The architecture of complexity. Sciences of the artificial (3rd ed). Cambridge, MA: MIT Press.

[2] Alvares, S. and Barney, J.A. (2007). Discovery and creation: alternative theories of entrepreneurial action. Strategic Entrepreneurship Journal, 1 (1-2), 11-26.

[3] Sarasvathy, S. (2001). Causation and effectuation: Toward a theoretical shift from economic inevitability to entrepreneurial contingency. Academy of Management Review, 26(2), 243-263.

[4] Eisenhardt, K.M. and Martin, J.A. (2000). Dynamic capabilities: what are they? Strategic Management Journal, 21. 1105-1121.

[5] Karbalevich, V. (2002). The Belarusian model of transformation: Alaksandr Lukashenka's regime and the nostalgia for the Soviet past. International Journal of Sociology, 31(4), 7-21.

[6] Ivanova, Y.V. (2004). Belarus: Entrepreneurial activities in an unfriendly environment. Journal of East-West Business, 10(4), $29-54$.

[7] Ivy, J. and Perenei, A. (2020). Entrepreneurial networks as informal institutions in transitional economies. Entrepreneurship and Regional Development, 05-05, 1-31.

[8] Ivanova, Y.V. (2006). Ethics in an unethical environment or absence of ethics? The International Journal of Emerging Markets, 2(1), 84-92.

[9] Beswick, E. (2020). Tens of thousands of protesters flood Belarus streets putting pressure on Lukashenko. Euronews.

[10] BBC News (2020). Belarus unrest: Lukashenko steps up efforts to reassert control. BBC News. August 19, 2020.

[11] Wijen, F., and Ansari, S. (2007). Overcoming Inaction through Collective Institutional Entrepreneurship: Insights from Regime Theory. Organization Studies 28 (7), 1079-100.

[12] Ciarli, T., Lorentz, A., Valente, M., and Savona, M. (2018). Structural changes and growth regimes. Journal of Evolutionary Economics 29 (1), 119-76.

[13] Van Aken. J.E and Romme, A.G.L. (2009). Reinventing the future: adding design science to the repertoire of organization and management studies. Innovation Technology Entrepreneurship \& Marketing. 6(1), 5-12.

[14] Van Aken, J.E., Chandrasekaran, A., Halman, J. (2016). Conducting and publishing design science research. Journal of Operations Management, 47-48, 1-8.

[15] Winter, S.G. (2000). The satisficing principle in capability learning. Strategic Management Journal, Special Issue 21 (1011), 981-996.

[16] Winter, S.G. (2003). Understanding dynamic capabilities. Strategic Management Journal, 24 (10), 991-995.

[17] Van Aken, J.E. (2004). Management Research Based on the Paradigm of the Design Sciences: The Quest for Field-Tested and Grounded Technological Rules. Journal of Management Studies. 41(2), 219-246.

[18] Van Aken, J.E. (2005). Management Research as a design science. Articulating the research products of mode 2 knowledge production in management. British Journal of Management 16 , 19-36.

[19] Engel, Y., Kaandorp, M, and Elfring, T (2017). A dynamic process model of entrepreneurial networking under uncertainty. Journal of Business Venturing, 32: 35-51. 
[20] Schreyögg, G., and Kliesch-Eberl, M. (2007). How dynamic can organizational capabilities be? Towards a dual-process model of capability dynamization." Strategic Management Journal 28 (9), 913-33.

[21] Teece, D.J. (2012). Dynamic capabilities: Routines versus entrepreneurial action. Journal of Management Studies 49 (8), 1395-401.

[22] Kodithuwakku, S. (1997). Entrepreneurial process in an apparently uniform context: a study of rural farmers in Sri Lanka; PhD thesis. University of Sterling, Department of Management and Organization.

[23] McMullen, and Shepherd, (2006). Entrepreneurial action and the role of uncertainty in the theory of the entrepreneur. Academy of Management Review, 31(1), 132-152.

[24] Shane, S. and Venkataraman, S. (2000). The promise of entrepreneurship as a field of research. Academy of Management Review, 2000, 25(1), 217-226.

[25] Galkina, T., and Chetty, S. (2015). Effectuation and Networking of Internationalizing SMEs. Management International Review 55 (5), 647-76.

[26] Sarasvathy, S.D. (2008). Effectuation: Elements of Entrepreneurial Expertise. Edward Elgar, New. Horizons in Entrepreneurship Series.

[27] Baker, T., \& Nelson, R. E. (2005). Creating Something from Nothing: Resource Construction through Entrepreneurial Bricolage. Administrative Science Quarterly, 50(3), 329-366.

[28] Romme, A.G. (2003). Making a Difference: Organization as Design. Organizational Science, 14 (5), 558-573.

[29] Selden, P.D. and Fletcher D.E. (2015). The entrepreneurial journey as an emergent hierarchical system of artifact-creating processes. Journal of Business Venturing, 30 (4), 603-615.

[30] Hallen, B.L. and Eisenhardt, K.M. (2012). Catalyzing strategies and efficient tie formation: How entrepreneurial firms obtain investment ties, Academy of Management Journal, 55(1), 35-70.

[31] Simon, H. A. (1976). Administrative behavior: A study of decision-making processes in administrative organization (3rd ed.) Free Press.

[32] Knight, F. H., (1921). Risk, Uncertainty and Profit University. of Illinois at Urbana-Champaign's Academy for Entrepreneurial Leadership Historical Research Reference in Entrepreneurship.

[33] Downing, S. (2005). The social construction of entrepreneurship: narrative and dramatic processes in the coproduction of organizations and identities. Entrepreneurship Theory and Practice, 29, 185-204.

[34] Teece, D.J., Pisano, G., and Shuen, A. (1997). Dynamic capabilities and strategic management. Strategic Management Journal, 18, 509-33.

[35] Zahra, S.A., Sapienza, H.J., and Davidson, P. (2006) Entrepreneurship and dynamic capabilities: A Review, model and research agenda. Journal of Management Studies, 43 (4), 917-955.

[36] Autio, E., George, G. and O.Alexy (2011). International entrepreneurship and capability development - Qualitative evidence and future research directions. Entrepreneurship Theory \& Practice, January, 11-37.

[37] Churchill, V.C and Lewis, V.L. (1983). The five stages of small business growth. Harvard Business Review, 61(3), 30-50.
[38] Helfat, C. E., \& Peteraf, M. A. (2009). Understanding dynamic capabilities: progress along a developmental path. Strategic Organization, 7(1), 91-102.

[39] Gerring, J. (2007). Case Study Research: Principles and Practices. Cambridge University Press.

[40] George, A., and Bennett, A. (2005). Case Studies and Theory Development in the Social Sciences. The MIT Press.

[41] Ragin, C. (2000). Fuzzy Set Social Science, Chicago: University of Chicago Press.

[42] Van Evera, S. (1997). Guide to Methods for Students of Political Science, New York: Cornell University Press.

[43] Druckman, D. (2005). Doing Research. Methods of Inquiry for Conflict Analysis. Sage Publication, Thousand Oaks, London, Delhi.

[44] Ivy, J., Larty, J. and S. Jack. (2014). Social capital and venture development in a low-trust environment. 2014 Academy of Management Annual Meeting Best Paper Proceedings.

[45] Copi, I.M. and Cohen, C. (2001). Introduction to Logic. Pearson Publisher.

[46] Bruton, G.D. and Ahlstrom, D. (2003). An institutional view of China's venture capital industry: Explaining the differences between China and the West. Journal of Business Venturing, 18(2), 233-259.

[47] McKeever, E., Jack, S. and Anderson, A. (2015). Embedded entrepreneurship in the creative re-construction of place. Journal of Business Venturing, 30(1), 50-65.

[48] Read, S., Dew, N., Sarasvathy, S. D., Song, M., \& Wiltbank, R. (2009). Marketing under Uncertainty: The Logic of an Effectual Approach. Journal of Marketing, 73(3), 1-18.

[49] Hambrick, D. C. (1994). What if the Academy Actually Mattered? Academy of Management Review, 19 (1), 11-16.

[50] Hitt, M.A. (1998). Presidential address - Twenty-first century organizations: Business firms, business schools, and the Academy. Academy of Management Review, 23, 218-224.

[51] Petticrew, M. (2001). Systematic view from astronomy to zoology: Myths and misconceptions. British Medical Journal $322,98-101$.

[52] Nan de Ven, A.H. (2002). Presidential address - Strategic directions for the Academy of Management: This Academy is for you! Academy of Management Review, 27, 171-184.

[53] Tsui, A.S. (2013). Presidential address - on compassion in scholarship: Why should we care? Academy of Management Review, 38(2), 167-181.

[54] Cardon, M.S., Stevens, C.E., and Potter, D.R. (2011). Misfortunes or mistakes? Cultural sensemaking of entrepreneurial failure. Journal of Business Venturing 26, 79-92.

[55] Grossman, E.B., Yli-Renko, H. and Janakiraman, R. (2012). Resource search, interpersonal similarity, and network tie valuation in nascent entrepreneurs' emerging networks. Journal of Management 38: 1760-1787.

[56] Jack, S.L. (2010). Approaches in studying networks: Implications and outcomes. Journal of Business Ventures 25 (1), 120-137.

[57] Gedajlovic, E., Honig, B., Moore, C.B., Payne, G.T., and Wright, M. (2013). Social capital and entrepreneurship: A schema and research agenda. Entrepreneurship Theory \& Practice 37 (3): 455-478. 
[58] Hoang, H. and Antoncic, B. (2003). Network-based research in entrepreneurship: a critical review. Journal of Business Venturing 18 (2), 165-187.

[59] Shepherd, D.A. and Haynie, J.M. (2011). Venture failure, stigma, and impression management: A self-verification, self-determination view. Strategic Entrepreneurship Journal, 5(2), 178-197.

[60] Aslund, A. (2002). Building Capitalism. The Transformation of the Former Soviet Bloc. Cambridge University Press.

[61] Puffer, S.M., McCarthy, D.J. and Boisot, M.H. (2010). Entrepreneurship in Russia and China: The Impact of Formal Institutional Voids. Entrepreneurship Theory and Practice, 34(3), 441-467.

[62] Weick, K.E. (1996). Drop your tools: An allegory for organizational studies. Administrative Science Quarterly, 41, 301-314.
[63] Rasche, A. \& Behnam, M. (2009). As if it were relevant. A system of theoretical perspective on the relation between science and practice. Journal of Management Inquiry, 18(3), 243-255.

[64] Starkey, K. and Madan, P. (2001). Bridging the relevance gap: Aligning stakeholders in the future of management research. British Journal of Management, 12, S3-26.

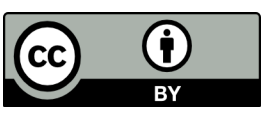

(C) 2020 by the Julia Ivy. Submitted for possible open access publication under the terms and conditions of the Creative Commons Attribution (CC $\quad$ BY) license (http://creativecommons.org/licenses/by/4.0/). 